\title{
Penerapan Pembelajaran Kooperatif Tipe Numbered Head Together Dalam Meningkatkan Hasil Belajar Bahasa Inggris Siswa
}

\author{
Burhanuddin \\ SMKN 1 Soppeng Kabupaten Soppeng Sulawesi Selatan \\ Bur.oke@gmail.com
}

\begin{abstract}
ABSTRAK
Tujuan penelitian ini untuk mengetahui hasil belajar Bahasa Inggris setelah diterapkan model pembelajaran Number Head Together (NHT) pada siswa Kelas XII Perhotelan SMKN 1 Watansoppeng Kabupaten Soppeng. Penelitian ini adalah penelitian tindakan kelas dengan 4 tahap yaitu planning, acting, observing dan reflecting yang dilaksanakan sejumlah dua siklus dengan tiga kali pertemuan tiap siklus. Data dikumpulkan melalui tes dan non tes. Tes dilakukan untuk melihat hasil belajar siswa sedangkan non tes (observasi dan perekaman) dimaksudkan untuk melihat aktivitas yang terjadi selama proses pembelajaran berlangsung. Data dianalisis dengan menggunakan teknik analisis kualitatif dan analisis kuantitatif. Sedangkan teknik validasi data dilakukan dengan saturasi dan trianggulasi. Hasil penelitian menunjukkan bahwa skor rata-rata hasil belajar siswa pada siklus I sebesar 78,00 dan pada siklus II mengalami peningkatan 86,00 . Persentase ketuntasan siswa pada siklus I sebesar $66,66 \%$ dan siklus II sebesar $100 \%$. Hasil penelitian dari observasi menunjukkan bahwa ada peningkatan kualitas aktivitas pembelajaran dari siklus I ke siklus II dari segi kehadiran, keaktifan dalam pembelajaran serta keterlibatan dalam bekerja kelompok, bertanya dan merespon dengan menggunakan bahasa Inggris.
\end{abstract}

\section{Kata kunci: Hasil Belajar, Number Head Together}

\section{ABSTRACT}

The purpose of this study was to determine the results of learning English after the implementation of the Number Head Together (NHT) learning model in Class XII Hospitality students of SMKN 1 Watansoppeng, Soppeng Regency. This research is a classroom action research with 4 stages, namely planning, acting, observing and reflecting which is carried out in two cycles with three meetings per cycle. Data were collected through tests and non-tests. Tests are conducted to see student learning outcomes while non-tests (observation and recording) are intended to see activities that occur during the learning process. Data were analyzed using qualitative analysis techniques and quantitative analysis. While the data validation technique was done by saturation and triangulation. The results showed that the average score of student learning outcomes in cycle I was 78.00 and in cycle II had an increase of 86.00. The percentage of student completeness in the first cycle is $66.66 \%$ and the second cycle is $100 \%$. The results of the research from observations indicate that there is an increase in the quality of learning activities from cycle I to cycle II in terms of attendance, activeness in learning and involvement in group work, asking questions and responding in English.

\section{Keywords: Learning Outcomes, Number Head Together}

\section{PENDAHULUAN}

Bahasa merupakan alat komunikasi yang sangat penting bagi kehidupan manusia, karena disamping berfungsi sebagai alat untuk menyatakan pikiran dan perasaan orang lain, sekaligus berfungsi sebagai alat untuk memahami pikiran dan perasaan orang lain. Kemampuan berbahasa tidak hanya diperlukan oleh manusia yang sudah dewasa saja tetapi juga diperlukan bagi remaja dan anak-anak. Oleh karena itu untuk menguasai kemampuan berbahasa tersebut dapat diwujudkan oleh proses pembelajaran.

Proses pembelajaran bahasa Inggris di sekolah adalah salah upaya untuk membekali peserta didik agar bukan hanya memiliki pengetahuan akan tetapi juag memiliki keterampilan. Pengetahuan dalam hal ini adalah peserta didik memiliki pemahaman tentang konsep-konsep tertentu. Pemahaman tersebut antara lain pemahaman tentang konsep tenses, active dan passive voice, regular dan irregular verb, singular dan plural serta materi-materi 
yang lain sesuai dengan tingkatan peserta didik tersebut. Pada kenyataannya ada beberapa anak yang memiliki pemahaman terhadap konsep tersebut akan tetapi lemah pada tataran keterampilan baik itu keterampilan menyimak, keterampilan berbicara, keterampilan menulis maupun keterampilan membaca.

Berdasarkan pengalaman penulis sebagai guru bahasa Inggris di SMKN 1 Watansoppeng bahwa pemahaman konsep peserta didik masih kurang begitu terhadap aspek keterampilannya. Salah satu yang menjadi penyebab kurangnya kemampuan peserta didik tersebut terhadap aspek keterampilan adalah minimnya keterlibatan siswa dalam berkomunikasi langsung baik terhadap sesama siswa maupun komunikasi terhadap guru saat proses pembelajaran. Hal lain yang menjadi permasalahan dalam pembelajaran bahasa Inggris adalah siswa tertentu merasa minder dengan temannya yang lebih pintar sehingga mereka menutup diri untuk terlibat secara aktif. Oleh karena itu perlu dilakukan suatu pembelajaran yang dapat memacu dan memicu keterlibatan aktif siswa serta menjembatani untuk untuk membuka gap pemisah antara siswa yang cepat daya tangkapnya dan siswa yang lambat pemahamannya.

Untuk dapat meningkatkan keterlibatan aktif siswa maka peran sentral guru sangat menentukan memilih model dan metode pembelajaran. Menurut James dikutip oleh Uno ( 2011:109) bahwa tugas dan peran guru antara lain, yaitu menguasai dan mengembangkan meteri pembelajaran, merencanakan dan menyiapkan pelajaran setiap hari, mengontrol dan mengevaluasi kegiatan siswa. Dalam konteks perencanaan itu tentu guru harus merencanakan model pembelajaran inovatif sehingga keterlibatan siswa dalam pembelajaran semakin besar.

Pemilihan model pembelajaran yang tepat amat penting untuk dilakukan. Meskipun pemilihan materi yang dipilih sudah tepat, jika model pembelajaran yang diterapkan kurang sesuai mungkin tujuan yang diharapkan tidak tercapai dengan baik. Jadi, model pembelajaran merupakan salah satu komponen pembelajaran yang penting dalam keberhasilan proses pembelajaran.

Model pembelajaran yang digunakan dalam pembelajaran sebaiknya adalah model pembelajaran yang memberikan interaksi guru dengan siswa, serta interaksi antar siswa yang nantinya akan membentuk sinergi yang menguntungkan untuk semua anggota (Lie, 2008: 33). Salah satu model pembelajaran yang dapat meningkatkan kemampuan pemahaman konsep bahasa Inggris dan melatih keterampilan adalah model Number Head

Together (NHT). Model pembelajaran kooperatif tipe NHT ini pada dasarnya merupakan sebuah diskusi kelompok yang heterogen. Pembelajaran yang mengembangkan diskusi dan kerja kelompok akan memberikan aktivitas lebih banyak pada siswa.

NHT merupakan suatu model pembelajaran yang melibatkan siswa secara aktif dalam menelaah materi yang tercakup dalam suatu pelajaran. Pada pembelajaran ini setiap siswa akan diberi nomor yang berbeda untuk setiap kelompoknya. Trianto (2009:8283) memberi penjelasan bahwa ada empat fase sebagai sintaks NHT yaitu: penomoran, pengajuan pertanyaan, berpikir bersama dan menjawab.

Dalam kegiatan pembelajaran dengan model number head together (NHT) mengikuti sintaks yaitu:

\begin{tabular}{|c|c|c|}
\hline Nomor & Fase & Kegiatan \\
\hline 1 & penomoran & $\begin{array}{l}\text { Guru membagi siswa ke dalam kelompok } 3-5 \text { orang dan } \\
\text { kepada setiap anggota kelompok diberi nomor antara } 1 \\
\text { sampai } 5 \text {. }\end{array}$ \\
\hline 2 & $\begin{array}{l}\text { Mengajukan } \\
\text { pertanyaan }\end{array}$ & $\begin{array}{l}\text { Guru memberikan pertanyaan-pertanyaan kepada siswa. } \\
\text { Pertanyaan dapat bervariasi dari yang bersifat spesifik } \\
\text { hingga yang bersifat umum. }\end{array}$ \\
\hline 3 & Berpikir bersama & $\begin{array}{l}\text { Siswa dalam kelompok berpikir bersama untuk } \\
\text { menggambarkan dan meyakinkan bahwa tiap orang } \\
\text { mengetahui jawaban tersebut }\end{array}$ \\
\hline 4 & menjawab & $\begin{array}{l}\text { Guru memanggil satu nomor siswa secara acak, kemudian } \\
\text { siswa yang nomornya sesuai mengacungkan tanggannya dan } \\
\text { mencoba untuk menjawab pertanyaan untuk seluruh kelas }\end{array}$ \\
\hline
\end{tabular}

Sumber: Trianto (2009:82-83) 
Rumusan masalah yang akan dikaji dalam penelitian ini adalah apakah pembelajaran kooperatif tipe Numbered Head Together dapat meningkatkan hasil belajar Bahasa Inggris siswa Kelas XII Perhotelan SMKN 1 Watansoppeng Kabupaten Soppeng provinsi Sulawesi Selatan?

Tujuan penelitian ini adalah untuk mengetahui hasil belajar bahasa Inggris siswa Kelas XII Perhotelan SMKN 1 Watansoppeng Kabupaten Soppeng tahun pelajaran 2014/2015 pada semester genap setelah diterapkan pembelajaran kooperatif tipe Numbered Head Together

\section{METODE PENELITIAN}

Penelitian ini dilaksanakan di SMKN 1 Watansoppeng Kabupaten Soppeng pada tahun pelajaran 2015. Subjek penelitian ini adalah siswa kelas XII Perhotelan semester genap tahun ajaran 2014/2015 yang berjumlah 18 orang, terdiri dari 7 laki-laki dan 11 perempuan. Objek penelitian adalah penerapan pembelajaran kooperatif dengan model Number Head Together (NHT). Sasaran penelitian adalah hasil belajar bahasa Inggris siswa kelas XII Perhotelan serta aktivitas siswa selama mengikuti pembelajaran bahasa Inggris. Penelitian dilaksanakan dalam bentuk penelitian tindakan kelas yang berbentuk siklus yaitu perencanaan (planning), pelaksanaan (acting), pengamatan (observing), dan refleksi (reflecting). Menurut Supardi \& Suhardjono ( 2011: 85) PTK dilaksanakan dalam bentuk yang berulang yang di dalamnya terdapat empat tahapan utama yaitu: (a) perencanaan, (b) tindakan, (c) pengamatan, dan (d) refleksi. Di setiap siklus dilakukan tiga kali pertemuan yang mana pada pertemuan ketiga dilakukan evaluasi untuk melihat hasil belajar siswa.

Teknik pengumpulan data yang dapat dipilih yaitu pengalaman, pertanyaan, dan penyelidikan. Pengumpulan melalui pengalaman yang digunakan yaitu observasi, pengumpulan data melalui pertanyaan yaitu test sedangkan pengumpulan data melalui penyelidikan yaitu dan perekaman. Mills (2003:71), in collecting data of Classroom Action Research, there are three techniques that can be selected by the researcher namely experiencing, enquiring, and examining.

Analisis data dalam penelitian ini dilakukan secara bersama dengan pengumpulan data. Sebagaimana Wiriatmadja (2005:147) mengatakan bahwa analisis data dalam penelitian tindakan kelas dilakukan bersamasama dengan pengumpulan data.

Data dalam penelitian ini terdiri atas 2 data yaitu data kualitatif dan data kuantitatif. Data kualitatif diambil dari observasi sedangkan data kuantitatif diambil dari hasil test. Data-data tersebut selanjutnya dianalisis dengan menggunakan analisis kualitatif yaitu peneliti melakukan refleksi diri melalui analisis, klarifikasi, interpretasi dan pengambilan kesimpulan. Data kuantitatif dianalisis dengan analisis kuantitatif melalui pemaparan data dalam bentuk persentase, median, standar defiasi yang ditampilkan melalui tabel dan diagram.

Adapun untuk keperluan analisis kualitatif akan digunakan teknik kategorisasi dengan skala lima berdasarkan standar yang ditetapkan oleh Departemen Pendidikan dan Kebudayaan (1993: 6) yaitu:

Untuk skor $0 \%$ - 34\% dikategorikan "sangat rendah"

Untuk skor 35\% - 54\% dikategorikan "rendah" Untuk skor 55\% - 64\% dikategorikan "sedang" Untuk skor $65 \%$ - 84\% dikategorikan "tinggi" Untuk skor $85 \%$ - 100\% dikategorikan "sangat tinggi"

Selanjutnya, ketuntasan belajar dikategorikan dengan menggunakan kriteria sebagai berikut: Tingkat penguasaan $0 \%-77 \%$ dikategorikan tidak tuntas.

Tingkat penguasaan $78 \%-100 \%$ dikategorikan tuntas.

Analisis untuk data hasil observasi aktivitas siswa dalam pembelajaran dihitung dengan menggunakan rumus sebagai berikut: persentase $\frac{\sum \text { siswa yang melakukan aktiviats }}{\sum \text { seluruh siswa }} \times 100 \%$

Untuk mengetahui keberhasilan dari penelitian ini dan pengujian hipotesis tindakan ditetapkan indikator sebagai berikut:

1. Meningkatnya hasil belajar bahasa Inggris siswa dari siklus I ke siklus II yang diperoleh melalui analisis rata-rata hasil tes siklus I dan siklus II.

2. Meningkatnya persentase siswa yang tuntas belajar dari siklus I ke siklus II. Siswa dikatakan tuntas secara individu jika mencapai batas KKM sebesar 78 dan tuntas secara klasikal jika $85 \%$ siswa mencapai nilai batas KKM 78

3. Meningkatnya aktivitas siswa dalam proses pembelajaran. 


\section{HASIL \& PEMBAHASAN}

Data hasil belajar siklus 1

Table 1

Distribusi Frekuensi dan Persentase Skor Hasil Belajar Bahasa Inggris Siswa kelas XII Perhotelan pada Siklus I

\begin{tabular}{cccc}
\hline Skor & Kategori & Frekuensi & Persentase (\%) \\
\hline $0-34$ & Sangat rendah & 0 & 0 \\
$35-54$ & Rendah & 0 & 0 \\
$55-64$ & Sedang & 2 & 11,11 \\
$65-84$ & Tinggi & 14 & 77,77 \\
$85-100$ & Sangat tinggi & 2 & 11,11 \\
\hline \multicolumn{2}{l}{ jumlah } & 18 & 100 \\
\hline
\end{tabular}

Tabel 1 menunjukkan bahwa dari 18 siswa, ada 2 orang atau $11,11 \%$ berada pada kategori sedang, 14 siswa $(77,77 \%)$ berada pada kategori tinggi dan 2 siswa $(11,11 \%)$ berada pada kategori sangat tinggi.

Tabel 2

Deskripsi Ketuntasan Belajar Siswa Kelas XII Perhotelan SMKN 1 Watansoppeng Siklus I

\begin{tabular}{|c|c|c|c|}
\hline Persentase skor & Kategori & Frekuensi & Persentase $(\%)$ \\
\hline $0 \%-77 \%$ & Tidak tuntas & 6 & 33,33 \\
\hline $78 \%-100 \%$ & Tuntas & 12 & 66,66 \\
\hline \multicolumn{2}{|c|}{ Jumlah } & 18 & 100 \\
\hline
\end{tabular}

Tabel 2 menunjukkan bahwa persentase ketuntasan kelas sebesar 66,66\% yaitu 12 siswa dari 18 termasuk dalam kategori tuntas dan 33,33\% atau 6 siswa dari 18 termasuk dalam kategori tidak tuntas. Ini berarti terdapat 6 siswa yang perlu perbaikan karena A. Data hasil belajar siklus 2 belum mencapai kriteria ketuntasan minimal. Hal ini juga menunjukkan bahwa ketuntasan klasikal belum mencapai $85 \%$ sehingga perlu dilanjutkan pada siklus 2 dengan membenahi kelemahan-kelemahan pada siklus 1 tersebut.

Tabel 3

Distribusi Frekuensi dan Persentase Skor Hasil Belajar Bahasa Inggris Siswa Kelas XII Perhotelan SMKN 1 Watansoppeng Pada Siklus II

\begin{tabular}{c|c|c|c|}
\hline Skor & Kategori & Frekuensi & Persentase (\%) \\
\hline $0-34$ & Sangat rendah & 0 & 0 \\
$35-54$ & Rendah & 0 & 0 \\
$55-64$ & Sedang & 0 & 0 \\
$65-84$ & Tinggi & 6 & 33,33 \\
$85-100$ & Sangat tinggi & 12 & 66,66 \\
\hline \multicolumn{2}{c}{ Jumlah } \\
\hline
\end{tabular}

Data pada tabel 3 di atas menunjukkan nilai siswa berada dua kategori yaitu tinggi dan sangat tinggi. Pada kategori tinggi sebesar
$33,33 \%$ dan kategori sangat tinggi sebesar $66,66 \%$

Tabel 4.

Deskripsi Ketuntasan Belajar Siswa Kelas XII Perhotelan SMKN 1 Watansoppeng Siklus II

\begin{tabular}{|c|c|c|c|}
\hline Persentase skor & Kategori & Frekuensi & Persentase $(\%)$ \\
\hline $0 \%-77 \%$ & Tidak tuntas & 0 & 0 \\
\hline $78 \%-100 \%$ & Tuntas & 18 & 100 \\
\hline \multicolumn{2}{|c|}{ Jumlah } & 18 & 100 \\
\hline
\end{tabular}


Data pada table 4 tersebut di atas menggambarkan bahwa sebesar 100\% siswa memperoleh ketuntasan dalam pelajaran bahasa Inggris.

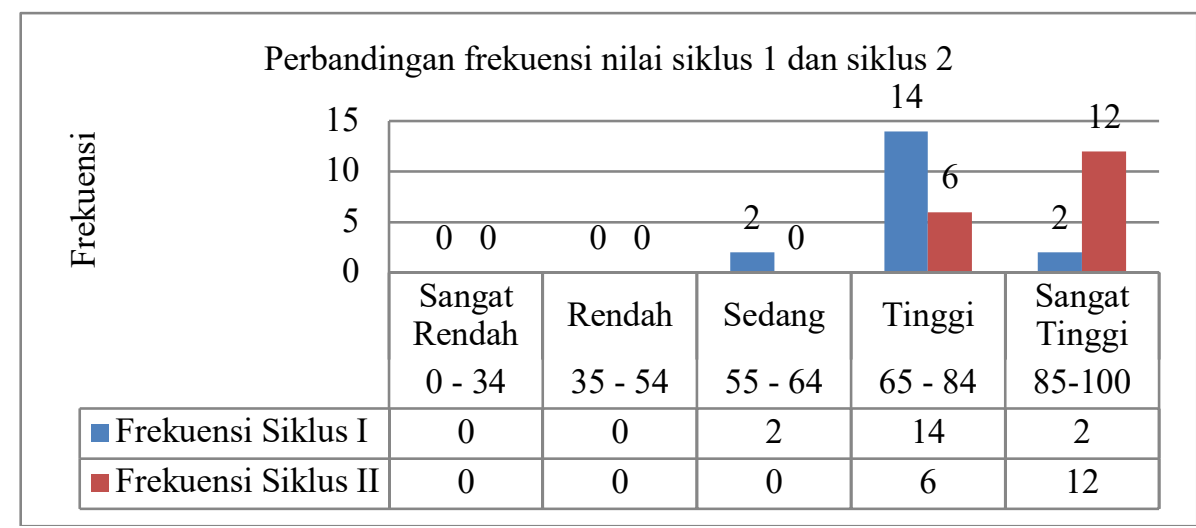

Gambar 1

Perbandingan frekwensi nilai siklus I dan II

Gambar 1 di atas menunjukkan bahwa ada peningkatan nilai pada kategori sedang dan sangat tinggi. Pada siklus I ada dua orang mendapat nilai pada rentang 55-64 sedangkan pada siklus 2 sudah tidak ada. Selanjutnya pada kategori sangat tinggi (85-100) pada siklus 1 ada dua orang $(11,11 \%)$ sedangkan pada siklus 2 menjadi 12 orang $(66,66 \%)$. Itu artinya bahwa ada peningkatan sejumlah 10 orang siswa atau $55,55 \%$.

Dalam hal aktivitas siswa terjadi peningkatan dari siklus pertama hingga siklus dua. Beberapa siswa yang cendrung bersikap tertutup pada siklus pertama beransur-ansur menjadi terbuka, periang, memiliki motivasi, terciptanya kerjasama yang tinggi, menghasilkan energy yang positif, meningkatkan penghargaan diri. Hal ini mendukug pendapat Joyce et al (2011:302) bahwa sinergi yang ditingkatkan dalam bentuk kerja sama akan meningkatkan motivasi jauh lebih besar dari pada dalam bentuk lingkungan kompetitif individual. Perasaa-perasaan saling berhubungan (feelings of connectedness) menghasilkan energy positif. Kerja sama mengingkatkan penghargaan diri, tidak hanya melalui pembelajaran yang terus berkembang, namun juga melalui perasaan dihormati dan dihargai oleh orang lain dalam sebuah lingkungan. Siswa yng mengalami dan menjalani tugas serta merasa harus bekerja sama dapat meningkatkan kapasitasnya untuk bekerja sama secara produktif

\section{KESIMPULAN \& SARAN}

Kesimpulan dari penelitian ini adalah:

1. Model pembelajaran kooperatif tipe number head together (NHT) dapat meningkatkan hasil belajar siswa Kelas XII Perhotelan SMKN 1 Watansoppeng, dengan rerata skor pada siklus 1 sebesar 78,00 menjadi 86,00 pada siklus II. Begitu juga median pada siklus I yaitu 79 menjadi 86 pada siklus II pada materi understanding simple business letter dan writing simple business letter and report.

2. Model pembelajaran kooperatif tipe number head together (NHT) dapat meningkatkan rasa percaya diri siswa untuk bertanya baik kepada guru maupun kepada temannya tentang materi yang tidak dimengerti serta meningkatnya kehadiran siswa dalam pembelajaran.

Selanjutnya saran-saran yang diajukan yaitu:

1. Kepada guru yang lain dapat mencoba menerapkan model pembelajaran kooperatif tipe number head together (NHT) dalam proses belajar mengajar dengan memperhatikan kecukupan dan kedalaman materi.

2. Penerapan model pembelajaran NHT akan lebih baik digunakan pada kelas yang jumlah siswa yang maksimal 20 siswa agar setiap siswa pada suatu kelompok dapat mendapatkan bagian pertanyaan dan atau mempresentasikan tugas yang diberikan

3. Pembentukan kelompok sebaiknya mempertimbangkan kemampuan akademik dan memperhatikan setiap karakter siswa agar kegiatan diskusi kelompok dapat berjalan dengan baik. 


\section{DAFTAR PUSTAKA}

Depdikbud. 2006. Sistem Penilaian Hasil Belajar Siswa. Jakarta: Departemen Pendidikan Nasional.

Joyce, Bruce., Weil, Marsha., Calhoun, Emily. 2011. Models of Teaching, Model-Model Pengajaran. Yogyakarta: Pustaka Pelajar.

Lie, Anita. 2008. Mempraktekkan Cooperative Learning di Ruang ruang Kelas. Jakarta: Grasindo.

Mills, Geoffrey. 2003. Action Research: A Guide for the Teacher Researcher. New Jersey: Prentice Hall

Supardi \& Suhardjono. 2011. Strategi Menyusun Penelitian Tindakan Kelas.Yogyakarta: ANDI Offset.

Trianto. 2009. Mendesain Model Pembelajaran Inovatif-Progresif. Jakarta: Kencana Prenada media Group.

Uno, Hamzah B., Nurdin, Mohamad. 2011. Belajar dengan Pendekatan PAILKEM (Pendekatan aktif, inovatif, lingkungan, kreatif, efektif dan menarik). Jakarta: PT. Bumi Aksara.

Wiriaatmadja, Rochiati. 2005. Metode Penelitian Tindakan Kelas.Bandung: PT. Remaja Rosdakarya. 